followed by the erection of a great new physical chemistry institute. "The Oxford school of chemistry will then be without doubt the finest in the Empire". The article ends with a plea for the award of college fellowships to more of the best of the young men holding University posts in science, especially in the less popular sciences-engineering, zoology, botany, geology. The same number of Oxford has noteworthy articles on "Politics or Poetry ?", on university camps for the unemployed (which have amply justified the money and effort expended on them), and on women as housing estate managers on the Octavia Hill system.

\section{Medical Research in South Africa}

MucH important research work is summarized in the annual report of the South African Institute for Medical Research for 1935. The use of a 'mixed vaccine' for the prevention of pneumonia among the Rand native miners has been continued with encouraging results. In the Biochemical Department, a strange finding was that the leaf of a plant belonging to the yam family contained forty times as much iron as spinach. Lucerne has been found to be suitable for human consumption as an anti-scorbutic, and several mines are now including this plant as part of their vegetable ration. The influence of South African snake venoms, previously tested on animal tumours, has now been tried on human cancers. Cobra venom often produced a relief of pain in cases of cancer, but not always; and no permanent beneficial effect resulted. There was no evidence that African snake venoms had any action on the majority of malignant tumours in man. Rodents to the number of 2,026 were examined for presence of plague infection, of which 51 were found to be infected with $B$. pestis.

\section{Standardization of Microscope Fittings}

IN order that the microscope objectives of different makers might be interchangeable for use with the microscope stands of other makers, the Royal Microscopical Society of London drew up in 1858 a specification for the screw thread of objective and of nosepiece. This specification was revised in 1896 , 1915 and 1924, and in its final form has been generally adopted by microscope makers at home and abroad. In view of the increasing use of apparatus above the eyepiece, a committee of the Society has now drafted specifications of standard sizes for the external diameter of the eyepiece end of the draw tube and limits for the outside diameter of the eyepiece shoulder; these have been adopted by the Council of the Society and are detailed in the December issue of its journal (J. Roy. Micro. Soc., 56, 377-380 ; 1936).

\section{The Smithsonian Institution}

THE report of the secretary of the Smithsonian Institution for the year ended June 30, 1936, refers to the continuation of the study of the relation of weather to changes in the sun's radiation. Two papers by Dr. C. G. Abbot appear to prove that the short interval changes of solar radiation are of major influence on the weather for at least the following two weeks. To test this promising method of weather forecasting, seven additional observing stations are required, but a bill to provide funds for this purpose passed by the Senate was rejected later. The Division of Radiation and Organisms has continued its work on the dependence of carbon dioxide assimilation in wheat upon the wave-length of radiation as well as its experiments on the effect of ultra-violet rays on algæ and of light of different wave-lengths on the growth of tomatoes. An extremely sensitive and quick-acting spectroscopic method has been developed for measuring the concentration of carbon dioxide, as well as a highly sensitive robust thermocouple. The Institution has also published the latest results of the high-altitude rocket experiments of Dr. R. H. Goddard, whose earlier work it supported for twelve years. In the most recent trial flights, the liquid-propelled rocket attained a height of 7,500 ft., its automatic stabilizer keeping the flight vertical. Sales of the Smithsonian Scientific Series continue to increase, and in addition to a summary of the work of the Institution and the financial report, the present report of the secretary includes appendixes giving more detailed accounts of the work of the National Museum, the Bureau of American Ethnology, the International Exchanges, the National Zoological Park, the Astrophysical Observatory, the Division of Radiation and Organisms, the Smithsonian Library, the National Gallery of Art and the Freer Gallery of Art.

\section{National Museum of Wales}

THE twenty-ninth annual report, for the year ending September 30, 1936, of the National Museum of Wales, gives evidence of steady progress. By an increase of $£ 500$, the Treasury annual grant for the year was raised to $£ 17,375$, and a detailed report, furnished to H.M. Treasury by the Council, and pointing to the increased expenditure necessitated by the opening of the east wing, had the effect of inducing an allocation of $£ 18,500$ for the current year and a promise of $£ 20,000$ per annum as from April 1, 1938. The increased grant has enabled the Council to found a Specimens Purchase Fund, to be applied to the purchase of collections or specimens of outstanding importance as the need arises, and to create a Department of Folk Culture and Industries, which was responsible for a special temporary exhibition of Welsh furniture. At that exhibition nearly a hundred examples of furniture, made or used in Wales, and ranging from Tudor to Georgian times, were gathered together. The list of free public lectures displays refreshing variety, and the installation of a $16 \mathrm{~mm}$. sound film apparatus should add to the popularity of the Reardon Smith Lecture Theatre.

\section{Dairy Research in Scotland}

THE seventh annual report of the Hannah Dairy Research Institute, Kirkhill, Ayr, contains an account of the developments, finance, and research work of 
the Institute during the year ending March 31, 1935. An important development has been a study of practical problems connected with grass conservation, made possible by a commercial grass-drying plant placed at the disposal of the Institute by the Agricultural Research Council. The condensing and drying of milk and the manufacture of canned milk products have also been investigated. Research work includes experiments on the nutritive value of milk for calves, the biochemistry of milk secretion, and studies on bovine tuberculosis, contagious bovine abortion and bovine mastitis. The pasteurization of milk and the bacteriological grading of milk have also been investigated. An inquiry into the consumption of milk by children of school age is in progress. As regards finance, State contributions and grants provide $£ 8,000$ a.year, but an additional $£ 2,000$ per annum is required if the Institute is to carry through its full programme of work.

\section{Social Services in the Soviet Plan for 1937}

According to the Soviet Union Year Book Press Service, the provisions of the 1937 Plan for the national economy of the U.S.S.R. in regard to the cultural and social services include the following: Science. $924 \cdot 2$ million roubles (about $£ 93$ million) for the maintenance of scientific institutions in 1937, as against 797.5 million roubles ( $£ 80$ million) in 1936 . Out of this sum, 245 million roubles (about $£ 25$ million) will be expended on general capital construction for the needs of science, to include an expenditure of 40 million roubles ( $£ 4$ million) on putting up new buildings to house the institutions of the All-Union Academy of Sciences, and 25 million roubles (about $£ 3$ million) for the building of the All-Union Institute of Experimental Medicine. Health Protection. A sum of $7,528 \cdot 1$ million roubles (£753 million) for health protection in 1937, as against $5,803 \cdot 5$ million roubles in 1936 . This sum includes an expenditure of 1,000 million roubles on buildings. The number of hospital beds in 1937 will be increased to 619,800 , as against 564,000 in 1936 ; maternity beds to 11,078 , as against 6,000 in 1936 .

\section{Truth and Propaganda}

AN article by Prof. M. Polanyi in The Manchester School, 7, No. 2, entitled "The Struggle between Truth and Propaganda", although a somewhat polemic criticism of S. and B. Webb's "Soviet Communism : a New Civilization", is of wider interest through its plea for a more determined stand by scientific workers and other intellectual workers for free and impartial criticism against propaganda. Unless thinkers make a fresh stand everywhere, regardless of political consequences, for the criticism which is freely admitted in a democracy, truth will remain powerless against propaganda, the power of which has been immensely enhanced by new means which scientific discoveries and their application have put in its hands. The reconciliation of rival social doctrines, which alone can save Europe from destruction, cannot be attained except through tolerance and the acceptance of truth and facts, no matter how unpalatable or disconcerting to particular theories.

\section{Germany and Science: Yesterday and To-day}

A CoRrespondent has pointed out that the speech at the Heidelberg jubilee by Reichsminister Rust, which was referred to in NATURE of January 16, p. 98, stands in poor contrast to an equally proud speech of Helmholtz delivered in 1869 (Les Mondes, 21, 552). Speaking at Innsbruck at a gathering of German scientific workers and medical men, he claimed that Germany held the first place in the development of natural sciences because the German savants, unlike their French and English colleagues, could proclaim truth as they found it, without regard to the opinion of the world, to social and religious prejudices. Our correspondent remarks that there was more of Athens than of Sparta in such men.

\section{Prof. H. E. Armstrong}

THE familiar and welcome figure of Prof. H. E. Armstrong has been missed in scientific circles for several months; and his caustic comments upon contemporary views and events-both scientific and unscientific-have similarly been absent from the pages of NATURE and of other periodicals. Though, however, general physical weakness prevents Prof. Armstrong from moving about and attending meetings in the way he has done all his life, yet he still takes active interest in progressive work of every kind and asks his friends not to hesitate to com. municate with him. He enters his ninetieth year on May 6, and maintains the indomitable and fearless spirit which has always characterized him. "I should like", he wrote a short time ago to an old friend, "to start over again in the hope that knowledge may be so made use of that some measure of tolerance and common sense will be infused into the nations."

\section{Seventh International Congress of Genetics}

THE following communication has been recoived from Prof. Otto L. Mohr, of the Anatomical Institute, University, Oslo, chairman of the International Committee for Genetics Congresses: "The VIIth International Genetics Congress which was going to be held at Moscow, U.S.S.R. this summer has been postponed. According to the information received from the Organization Committee, a number of scientists and institutes have requested this as they wished to be better prepared for the congress. The Academy of Sciences and the Organization Committee have now extended an invitation to hold the congress in Moscow in August, 1938. Conforming with the mandate given to the Permanent International Committee for Genetics Congresses, the entire matter will be put before this committee for decision. At present it is certain that no International Genetics Congress will be held in 1937."

\section{British Empire Cancer Campaign}

At the quarterly meeting of the Grand Council of the British Empire Cancer Campaign held on April 12 , the following grants, totalling $£ 2,900$, were made, in addition to the bulk grants of last November and January : $£ 1,000$ to be placed at the disposal of 